Plant Production Science

Available online at http://zjar.journals.ekb.eg http:/www.journals.zu.edu.eg/journalDisplay.aspx?Journalld=1\&queryType=Master

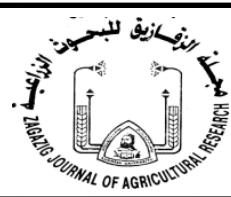

\title{
EFFECT OF INTERACTION BETWEEN WATER STRESS AND FOLIAR APPLICATION BY ASCORBIC ACID OR MICRONUTRIENTS ON MAIZE PRODUCTIVITY AND IRRIGATION WATER USE EFFICIENCY
}

\author{
Maher A. Kotb, A.A. Mohammed, M.M.M. El-Sayed* and Manal Sh. Abd El-Haliem \\ Agron. Dep., Fac. Agric., Suez Canal Univ., 41522 Ismailia, Egypt
}

\section{Received: 21/02/2021 ; Accepted: 11/04/2021}

\begin{abstract}
Two field experiments were conducted in a new soil in extention field in El QantraWest, Ismailia Governorate, Egypt during 2017 and 2018 summer seasons. The study aimed to evaluate the effect of six exogenous application levels of ascorbic acid (AsA) and micronutrients mixture on yellow corn hybrid 352 (three way cross) under three amounts of irrigation water (3750, 3000 and 2250 $\mathrm{m}^{3} / \mathrm{fad}$., of the estimated crop evapotranspiration) using surface irrigation system. A randomized complete block split plot design with three replicates was used in each season. The irrigation treatments and the levels of AsA and micronutrients mixture were randomly allocated in the main and sub-plots, respectively. The most important findings could be summarized as follows. Decreasing the amount of irrigation water from 3750 to $2250 \mathrm{~m}^{3} / \mathrm{fad}$., significantly diminished ear leaf blade area, relative water content and total chlorophyll at 85 days from sowing. Also, at harvest, ear length, 100-grain weight and grain yield/fad., were decreased, but irrigation water use efficiency (IWUE) was significantly ameliorated. Generally, foliar application by AsA or micronutrients mixture significantly increased these traits with increasing irrigation water use efficiency (IWUE) compared with their untreated analogues. The interaction between both studied factors showed that $350 \mathrm{ppm}$ AsA treatment protected about 500 $\mathrm{kg} / \mathrm{fad}$., grains from collapse under moderate and severe water stress. Application of AsA saved approximately $750 \mathrm{~m}^{3} / \mathrm{fad}$ of irrigation water without yield reduction under stress conditions.
\end{abstract}

Key words: Maize, AsA, IWUE, micronutrients, water stress, evapotranspiration.

\section{INTRODUCTION}

Maize is one of the most important cereal crops and is the third crop after wheat and rice. It plays a critical role in animals and human feeding not only in Egypt but also in almost countries. It is used for feeding animals in the form of grain and green fodder and enters in the manufacture of a very large number of products (FAO STAT, 2020). Drought stress is one of the main abiotic stresses and the major causes of osmotic stress to plants under natural marginal lands (Xiong and Zhu 2002). Water deficit-associated with high temperature or salinity or other stresses are often considered to be a limiting factors in corn plants (Zea mays L.) grown under arid and semiarid regions. About, one-third of the world's arable land is suffering from chronically inadequate supplies of water for cultivation

\footnotetext{
* Corresponding author: Tel.: +2 01008585188
}

E-mail address: en.3mzarka@ outlook.com
(Massacci et al. 2008). Water stress induced oxidative stress in two maize lines, the antioxidants of enzymatic and non-enzymatic significantly increased in these both maize lines (Moharramnejad et al., 2019). In addition, drought stress also induces oxidative stress which can cause plant death and decrease productivity at the whole-plant level. Also, exposure to drought stress can affect all the major plant processes, including photosynthesis, protein synthesis, energy and lipid metabolism (Apel and Hirt 2004).

Under drip irrigation, irrigation SC 10 maize hybrid by $1575 \mathrm{~m}^{3} / \mathrm{fad}$ instead of $2625 \mathrm{~m}^{3} / \mathrm{fad}$., of the estimated crop evapotranspiration significantly reduced ear leaf blade area, total chlorophyll, relative water content, grain yield and irrigation water use efficiency (Kotb et al., 2009). Lawlor 
and Cornic (2002) confirmed that the photosynthetic rates are known to be decrease as the relative water content decrease under water stress conditions. The obtaining of optimum leaf area index is very important for improving photosynthesis and dry matter productions in plants (Farooq et al., 2009). Drought imposed at initiation of silking was more lethal in terms of reduction in different yield and yield components including 1000-grain weight, grain and biological yields (Qasim et al., 2019). A complex antioxidative defense system, composed of both non-enzymatic and enzymatic constituents, is present in all plant cells (Foyer, 1993). Lowmolecular weight, non-enzymatic and nutrientderived antioxidants are presented by carotenoids, tocopherols, glutathione and ascorbic acid (AsA). Apart their obvious role as enzyme substrates, they can react chemically with almost all forms of ROS. AsA is a small, water-soluble antioxidant molecule that acts as a primary substrate in the cyclical pathway for detoxification and neutralization of superoxide radicals and singlet oxygen (Foyer, 1993).

Under normal and water stress conditions, the effects of foliar application of vitamin $\mathrm{C}$ (AsA) on many plants were indicated. Dolatabadian et al. (2010) found that foliar application of $150 \mathrm{mgl}^{-1}$ ascorbic acid during growing phases on corn increased grain weight. Also, foliar spray of 200ppm AsA improved leaf area, photosynthetic pigments (chl. a, chl. b and total chl.), 100-grains weight and grain yield and irrigation water use efficiency (Abo-Marzoka $\boldsymbol{e t}$ al., 2016; Qasim et al., 2019). Grain yield of wheat was increased by about $0.5 \mathrm{t} / \mathrm{ha}$ in AsAtreated plants under normal irrigation. Also, AsA treatments protected about 0.8-0.9 t/ha grains from collapse under water stress. Application of AsA saved approximately 852 $\mathrm{m}^{3} / \mathrm{h}$ of irrigation water without yield reduction (Kotb and Elhamahmy, 2013). Grzebisz et al. (2008) reported that the application of micronutrients is simple and easy method for improvement of plant nutritional condition for wheat and maize plants. So, the growth and yield of maize plants are adversely affected by nutrients stress conductions. The effects of micronutrient application such as $\mathrm{B}, \mathrm{Zn}, \mathrm{Cu}, \mathrm{Mn}$ and $\mathrm{Fe}$ on 100-grain weight of BARI Hybrid Maize 5 were statistically significant (Rahman et al. 2017). Under rainfed conditions, results of Wasaya et al. (2017) showed that leaf area index was significantly improved by combined application of $\mathrm{Zn}$ and $\mathrm{B}$ on foliage compared to untreated maize plants. On the other hand, using citrine fertilizers which contains $(15 \%$ citric acid, $2 \% \mathrm{Fe}, 2 \% \mathrm{Mn}$ and $2 \% \mathrm{Zn}$ ) as foliar application significantly improved growth and yield of maize plants (Tohidi Moghadam et al, 2013; El-Yazal, 2019). Also, Sajedi et al. (2011) found that with increasing the drought stress level, addition of micronutrients of $\mathrm{Fe}$ (2.6), $\mathrm{Zn}$ (4.1), $\mathrm{Cu}$ (1.5), Mn (2.6), B (1.5), Mo $(0.5)$ and $\mathrm{Mg}(4.1 \%)$ can alleviate the unfavorable effects of drought stress on corn plants by affecting plant metabolism. In the same direction, Yarnia et al. (2013) noticed that a mixture of all combinations of $\mathrm{N}, \mathrm{Mg}, \mathrm{Zn}, \mathrm{Mn}$, $\mathrm{B}$, at all stages had the highest grain yield of corn compared to untreated plants. Waraich $\boldsymbol{e t}$ al. (2011) found that the micronutrients like Fe, $\mathrm{B}, \mathrm{Mn}$ and Mo can enhance and improve the IWUE by alleviating the adverse effects of water stress indirectly by activating several metabolisms in crop plants like physiological, biochemical and metabolic processes.

The objective of this study is evaluate the effect of water stress and foliar application by ascorbic acid and micronutrients mixture in improving growth, yield and irrigation water use efficiency of maize under new soil conditions.

\section{MATERIALS AND METHODS}

Two field experiments were conducted in a new soil in the extension field in El QantraWest, Ismailia Governorate, Egypt $\left(30^{\circ} 58^{\prime} \mathrm{N}, 32^{0}\right.$ $23^{\prime} \mathrm{E}$, and $10 \mathrm{~m}$ above mean sea level) during 2017 and 2018 summer seasons. The study aimed to find out the effect of six exogenous application levels of AsA and micronutrients mixture (Fe: $6 \%$, Zn: 5\%, Mn: 2\%, Co: 0.30\%, B: $1.50 \%$, Mo: $0.50 \%$ ) on yellow corn hybrid 352 (three way cross) under three amounts of irrigation water (1.00. 0.80 and 0.60 of the estimated crop evapotranspiration) using surface irrigation system. A randomized complete block split plot design with three replicates was used in each season. The irrigation treatments and the levels of AsA and micronutrients mixtures were randomly allocated in the main and sub-plots, respectively. 
Three amounts of irrigation water were calculated as 1.0 (IR1), 0.8 (IR2) and 0.6 (IR3) of the estimated crop evapotranspiration (ETc). Maize plants were given 9 irrigations at 10 days intervals starting after 25 days from sowing. In the two growing seasons, the amount of water needed for each irrigation was calculated according to the crop coefficient $(\mathrm{Kc})$ and the daily reference potential evapotranspiration (ETo). The latter was determined according to the Penman-Monteith equation (Allen $\boldsymbol{e t}$ al., 1998) depending on the predicted climatic factors at each irrigation time and the growth stage of maize plant. As recommended by Allen et al. (1996) and Neale et al. (1996), the FAO Kc of maize plant were 0.40 for initial stage (20 day), 0.80 for crop development stage (35 day), 1.15 for mid-season stage (40 day) and 0.70 for lastseason stage (30 day). At the end of the last irrigation, the quantity of water applied for each of the three irrigation treatments was calculated according to the total amount of water added in the 9 irrigations for the two seasons. The average amounts of water during the two growing seasons were 3750,3000 and $2250 \mathrm{~m}^{3} / \mathrm{fad}$., for the irrigation treatments, respectively.

Six exogenous application levels of ascorbic acid and micronutrients mixture levels (S0: spray with tap water, S1:250 ppm AsA, S2: 350 ppm AsA, S3: 450 ppm AsA, S4: 100\% recommended dose of micronutrients mixture and $150 \%$ micronutrients mixture) were foliar applied in 100 liter /fad after 30, 50 and 70 days from sowing. Before beginning of the experiment, soil samples were obtained with an auger from soil depths of $0-60 \mathrm{~cm}$ to determine the physical and chemical properties of the experimental field (Table 1). The soil texture at this site was predominantly loamy throughout its profile (49.3\% sand, $37.2 \%$ silt and $13.5 \%$ clay). The Soil physical and chemical properties of the experimental field over the two seasons were determined following the method of Cassel and Nielsen (1986) and Grossmann and Reinsch (2002). The climate in this region is almost arid. The temperature averages approximately $28.0^{\circ} \mathrm{C}$ in summer; and the relative humidity averages approximately $58.0 \%$. The predicted monthly climatic data at Ismailia region during the growing seasons of maize are presented in Table 2.
The sowing date was 15 May in both seasons in hills $20 \mathrm{~cm}$ apart. The sub-plot area was 12 $\mathrm{m}^{2}$ included 5 ridges of $4 \mathrm{~m}$ long and $60 \mathrm{~cm}$ apart. The preceding crop was Egyptian clover in the two growing seasons. To ensure full germination and complete establishment of seedlings, the normal irrigation was applied to the all field area at planting up to starting the irrigation water treatments. Twenty days after sowing, maize plants were thinned to one plant/hill. The agronomic practices were done as recommended in this region.

At 85 days from sowing, five plants were randomly taken from the $2^{\text {nd }}$ ridge for estimating the vegetative growth characters as follows:

1- Ear leaf blade area $\left(\mathrm{cm}^{2}\right)$.

2- Relative water content (\%), was determined according to Schonfeld et al. (1988).

$$
\text { RWC }=\frac{\text { Fresh weight }- \text { dry weight }}{\text { Turgid weight- dry weight }} \times 100
$$

3- Total chlorophyll (SPAD value), was determined using the Minolta SPAD-502 chlorophyllmeter according to Markwell et al. (1995).

At maturity, yield measurements were estimated from plants of the two middle ridges (the $3^{\text {rd }}$ and $4^{\text {th }}$ ridges) in each sub plot.

1- Hundred grain weight ( $\mathrm{g}$ )

2- Grain yield ( $\mathrm{kg} / \mathrm{fad})$, it was adjusted to $15.5 \%$ moisture content.

3- Irrigation water use efficiency (IWUE) in $\mathrm{kg}$ $\mathrm{m}^{-3}$.

It was calculated as IWUE $=$ GY /IR $\times 100$, where GY is grain yield $(\mathrm{kg} / \mathrm{fad})$ and $I R$ is the amount of applied irrigation water $\left(\mathrm{m}^{3} / \mathrm{fad}\right)$ for each irrigation treatment.

\section{Statistical Analysis}

All data were analyzed using the COSTAT software, version 6.311 (CoHort software, Berkeley, CA 94701). The analysis of variance of a randomized complete block split plot design was used. The least significant difference (LSD at $\mathrm{P}$ $\geq 0.05$ ) was used to compare the differences among interactions means, according to Steel et al. (1997). Graphical presentation of data was carried out using Microsoft Excel program (Microsoft Corporation, Los Angeles, CA, USA). 
Table 1. Soil physical and chemical properties of the experimental field soil over the two seasons

\begin{tabular}{|c|c|c|c|c|c|c|c|c|}
\hline $\begin{array}{l}\text { Soil depth } \\
\text { (cm) }\end{array}$ & 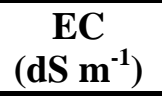 & pH & $\begin{array}{c}\text { Sand } \\
(\%)\end{array}$ & $\begin{array}{l}\text { Silt } \\
(\%)\end{array}$ & $\begin{array}{c}\text { Clay } \\
(\%)\end{array}$ & Texture & & \\
\hline $0-60 \mathrm{~cm}$ & 3.96 & 7.77 & 49.3 & 37.2 & 13.5 & Loamy & & \\
\hline \multirow{2}{*}{$\begin{array}{l}\text { Soil depth } \\
\quad(\mathrm{cm})\end{array}$} & \multicolumn{4}{|c|}{ Cations (meq/l) } & \multicolumn{4}{|c|}{ Anions (meq/l) } \\
\hline & $\mathrm{Ca}^{2+}$ & $\mathrm{Mg}^{2+}$ & $\mathrm{Na}^{+}$ & $\mathbf{K}^{+}$ & $\mathrm{CO}_{3}{ }^{2}-$ & $\mathrm{HCO}_{3}^{-}$ & $\mathrm{Cl}^{-}$ & $\mathrm{SO}_{4}{ }^{2-}$ \\
\hline $0-60 \mathrm{~cm}$ & 3.5 & 4.0 & 23.1 & 8.6 & - & 4.4 & 27.0 & 7.8 \\
\hline
\end{tabular}

Table 2. The predicted monthly climatic data at Ismailia Governorate during the growing periods of corn as average from 2015 to 2019 seasons

\begin{tabular}{|c|c|c|c|c|c|}
\hline \multirow[t]{2}{*}{ Months } & \multicolumn{3}{|c|}{ Average temperature ${ }^{0} \mathrm{C}$} & \multirow{2}{*}{$\begin{array}{c}\text { Average } \\
\text { Relative humidity } \\
\text { (RH \%) }\end{array}$} & \multirow{2}{*}{$\begin{array}{c}\text { Average } \\
\text { Wind speed } \\
(\mathrm{Km} / \mathbf{h})\end{array}$} \\
\hline & Minimum & Maximum & Average & & \\
\hline May & 14 & 36 & 25.0 & 47.5 & $\mathbf{1 5 . 5}$ \\
\hline June & 17 & 39 & 28.0 & 53.0 & 13.5 \\
\hline July & 19 & 39 & 29.0 & 60.5 & 14.0 \\
\hline August & 21 & 38 & 29.5 & 63.5 & 12.5 \\
\hline September & 19 & 36 & 27.5 & 64.5 & 11.5 \\
\hline
\end{tabular}

Data collected from Egyptian Meteorological Authority.

\section{RESULTS AND DISCUSSION}

The results and discussion were focus on the interaction effect of irrigation treatments and spraying treatments with AsA or micronutrients mixture on measured traits as following:

\section{Plant Growth}

\section{Ear leaf blade area $\left(\mathrm{cm}^{2}\right)$}

The results in Figs. 1 and 2 indicated that the interaction effects between the two studied factors were significant on ear leaf blade area in both seasons at 85 days from sowing. It is clear from these results that foliar application of AsA and micronutrients mixture alleviated the adverse effect of water stress on ear leaf blade area in both seasons at 85 days from sowing. The obtaining of optimum leaf area index is very important for improving photosynthesis and dry matter productions in plants (Farooq $\boldsymbol{e t}$ al., 2009). The maximum values of ear leaf blade area were significantly obtained from the interactions between normal condition with 350 or $450 \mathrm{ppm}$ AsA or recommended dose of micronutrients or from the interaction between moderate stresses with $350 \mathrm{ppm}$ AsA without significant differences among them in first season. Meanwhile, in the second season, the highest values of this trait were significantly obtained from the interaction between normal conditions with $350 \mathrm{ppm}$ AsA at 85 days from sowing. Kotb (2014) studied the effect of foliar application of non-enzymatic antioxidants (ascorbic acid; AsA) on peanut yield and its quality for sprinkler-irrigated peanut. Drought caused significant reduction in leaf area index. Meanwhile, exogenous application of AsA by a suitable level $(100 \mathrm{ppm})$ significantly increased leaf area index. On the same direction, Kotb and Elhamahmy (2013) studied the effect of AsA $(0.0,100$ and $200 \mathrm{ppm})$ on the response of wheat to three surface irrigation rates which represented 4260, 3408 and $2556 \mathrm{~m}^{3} / \mathrm{ha}$, respectively. The results stated that, water stress caused a decreasing in leaf area index. Meanwhile, spraying with AsA significantly improved this trait. Under rainfed conditions, results of Wasaya et al. (2017) showed that leaf area index was significantly improved by combined application of $\mathrm{Zn}$ and $\mathrm{B}$ on foliage compared to untreated maize plants. It has been established that under severe drought stress may result in the cessation of photosynthesis, metabolism disturbance consequence finally plant organs death (Smirnoff, 1993; Jaleel $\boldsymbol{e t}$ al., 2008). 


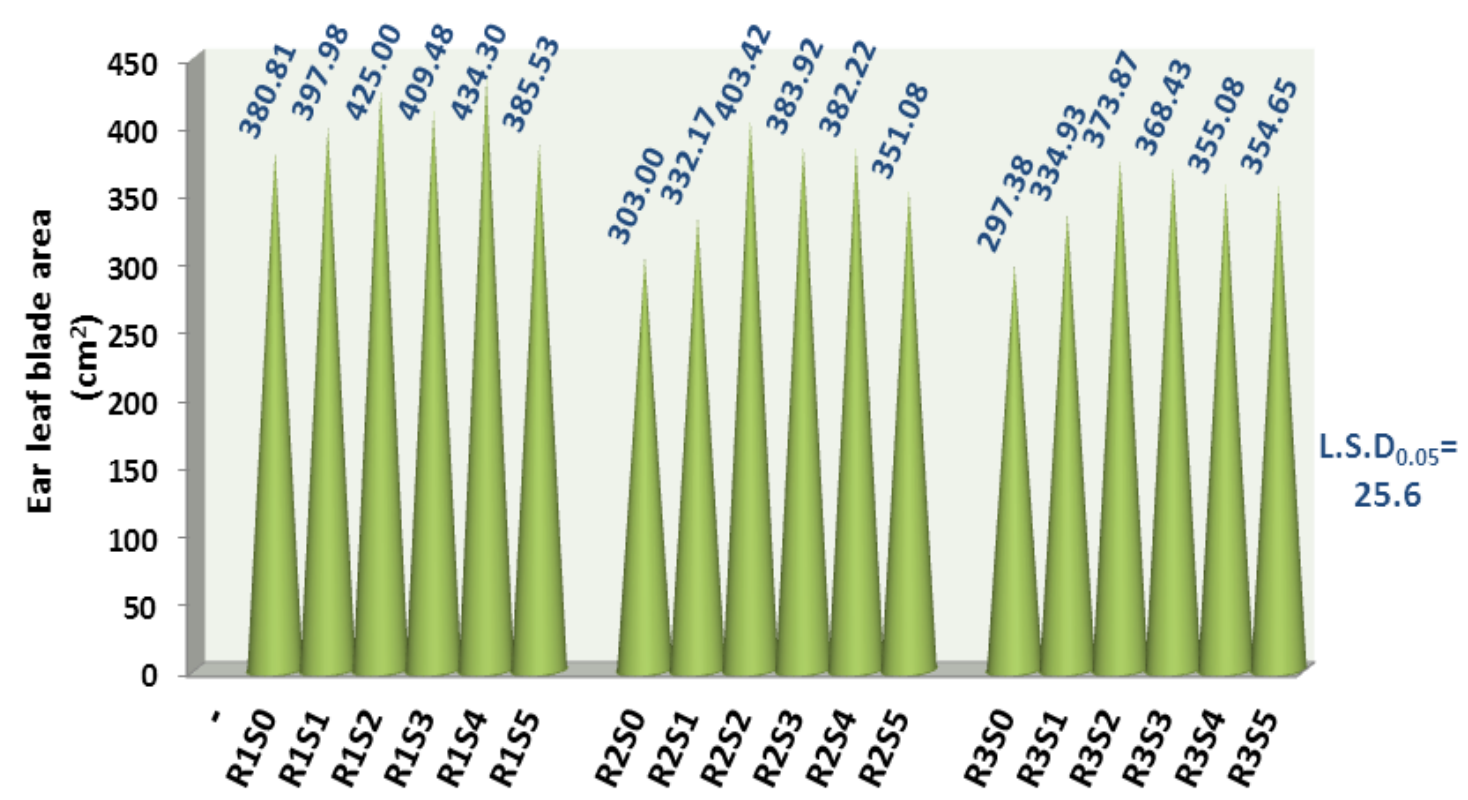

Figure 1. Effect of the interaction between water stress (R) and foliar spray (S) by AsA and micronutrients on Ear leaf blade area $\left(\mathrm{cm}^{2}\right)$ of maize at 85 days from planting in 2017 season. S0: untreated plants, S1: spray with 250 ppm AsA, S2: 350 ppm AsA, S3: 450 ppm ASA, S4: spray with 100\% micronutrient recommended dose and S5: $150 \%$ micronutrient. R1: well-watered ( $3750 \mathrm{~m}^{3} / \mathrm{fad}$ ); R2: 0.8 R1, R3: 0.6 of R1.

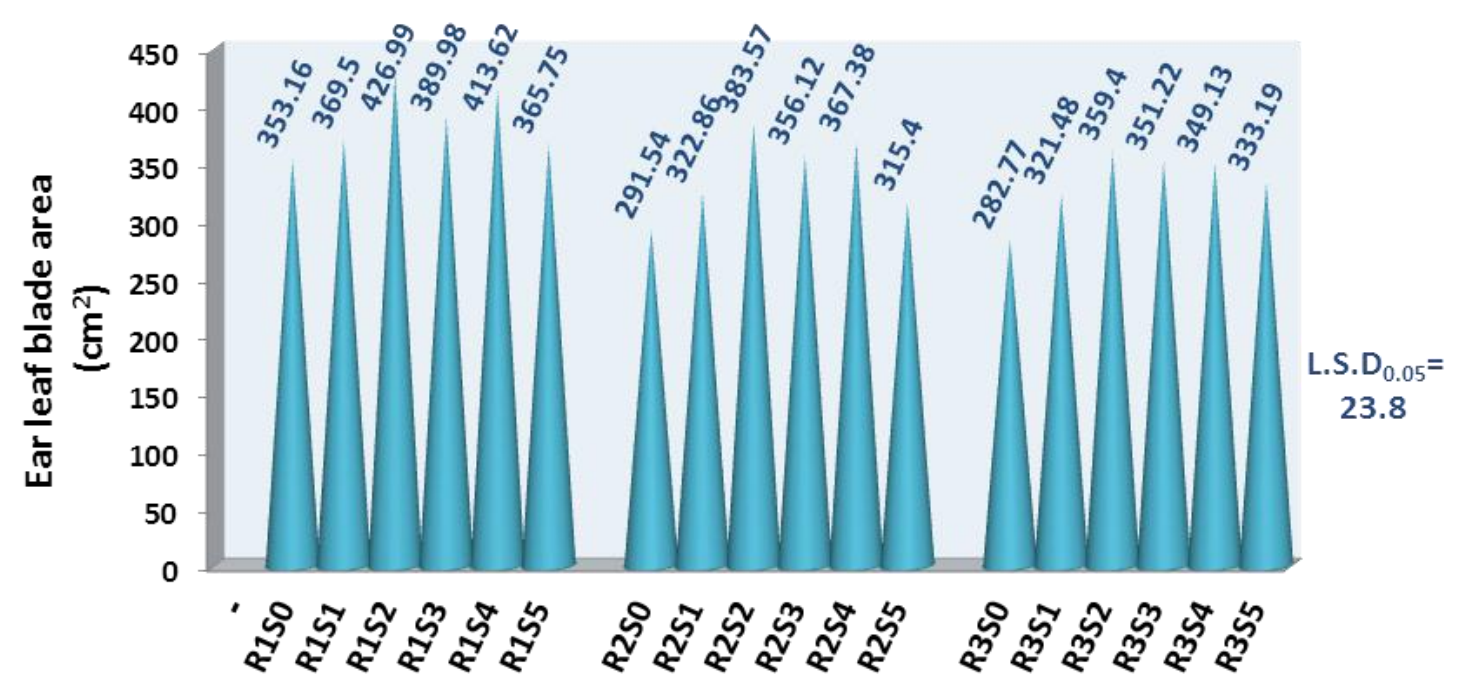

Figure 2. Effect of the interaction between water stress (R) and foliar spray (S) by AsA and micronutrients on Ear leaf blade area $\left(\mathrm{cm}^{2}\right)$ of maize at 85 days from planting in 2018 season. S0: untreated plants, S1: spray with 250 ppm AsA, S2: 350 ppm AsA, S3: 450 ppm ASA,

S4: spray with $100 \%$ micronutrient recommended dose and S5: $150 \%$ micronutrient. R1: well-watered ( $\left.3750 \mathrm{~m}^{3} / \mathrm{fad}\right)$; R2: 0.8 R1, R3: 0.6 of R1. 


\section{Relative water content (\%)}

Relative water content (RWC) was determined to give an indicator of the plant water status. Relative water content (RWC) was significantly affected by irrigation rate and by spraying with AsA and micronutrients mixture. Our results in the same Figs. 3 and 4 indicated that the interactions between the two studied factors significantly affected on the averages of leaves RWC at 85 days from planting in both seasons. In comparison with all other treatments under any conditions (1.0, 0.8 and 0.6 Etc) of the study, the highest values of RWC were significantly ameliorated by the interaction between $350 \mathrm{ppm}$ AsA and 1.0 Etc (100\% of the estimated crop evapotranspiration) and the interaction between $100 \%$ recommended dose of micronutrients and 1.0 Etc without significant differences between them in the two seasons (Figs. 3 and 4). In general, it was found that the concentration of $350 \mathrm{ppm}$ led to a significant improvement in the values of relative water content compared to untreated plants under same conditions ( 0.8 and 0.6 Etc). As average of two seasons and under moderate water stress, the values of this trait were increased by approximately $30 \%$. Meanwhile, under sever water stress; these values were ameliorated by about 24\% (Figs. 18 and 19). Water stress causes directly or indirectly reduction in the contents of relative water content of corn plants (Shlemmer $\boldsymbol{e t}$ al., 2005; Premachandra et al., 2008; Kotb et al., 2009). Kotb (2014) found that drought caused significant reduction in each of relative water content. Meanwhile, exogenous application of AsA by a suitable level enhanced this trait. Furthermore, El-Yazal (2019) recommend that using citrine fertilizers which contains $(15 \%$ citric acid, $2 \% \mathrm{Fe}, 2 \% \mathrm{Mn}$ and $2 \% \mathrm{Zn}$ ) as foliar application for improving growth and chemical constituents of maize plants. Also, Sajedi et al (2011) found that with increasing the drought stress level, addition of micronutrients of $\mathrm{Fe}$ (2.6), $\mathrm{Zn}$ (4.1), $\mathrm{Cu}$ (1.5), Mn (2.6), B (1.5), Mo $(0.5)$ and $\mathrm{Mg}(4.1 \%)$ can alleviate the unfavorable effects of drought stress on corn plants by affecting plant metabolism.

\section{Total chlorophyll (SPAD value)}

The results obtained from Figs. 5 and 6 revealed that the interactions between the irrigation rates and foliar spraying with ascorbic acid or micronutrients mixture significantly affected on total chlorophyll at 85 days from planting in both seasons. The highest contents of total CHL were significantly obtained by the interaction between $350 \mathrm{ppm}$ AsA and well watered $(1.0 \mathrm{Etc})$ in comparison with all other treatments under any conditions $(1.0,0.8$ and 0.6 Etc) of the study at 85 days from planting in both seasons. Generally, our results indicated that $350 \mathrm{ppm}$ AsA and recommended dose of micronutrients mixture led to a significant increment in the values of total chlorophyll compared to untreated plants under same conditions (0.8 and 0.6 Etc). Under moderate water stress, the values of this trait were ameliorated by about 23 and $14 \%$ in first season and by about 19 and 14\% in second season, respectively. Meanwhile, under severe water stress; these values were ameliorated by about 22 and $17 \%$ in first season and by about 25 and $20 \%$ in second season, respectively, (Figs. 5 and 6). Also, Reddy and Rao, 1968 noticed that severe water stress conditions decreased the contents of chlorophyll $a, b$, and total chlorophylls and produced changes in the ratio of chlorophyll ' $a$ ' and 'b' and carotenoids (Anjum et al., 2003; Farooq et al., 2009). These results are in harmony with those reported by Farahat $\boldsymbol{e t}$ al. (2007), Kotb and Elhamahmy (2013) and Kotb (2014). They found that drought caused significant reduction in this trait; meanwhile, exogenous application of AsA by a suitable level significantly ameliorated this trait. On the other hand, using citrine fertilizers which contains (15\% citric acid, $2 \% \mathrm{Fe}, 2 \% \mathrm{Mn}$ and $2 \% \mathrm{Zn})$ as foliar application significantly improved growth and yield of maize plants (Tohidi Moghadam et al., 2013; El-Yazal, 2019).

\section{At Harvest}

\section{Hundred grain weight (g)}

The significant interactions effects between the studied factors on 100-grain weight (g) are presented in the second season (Fig. 7). These results revealed that using intermediate level of ascorbic acid (350 ppm) with full irrigation significantly gave the highest 100 -grain weight $(26.41 \mathrm{~g})$ compared with the other interactions under all conditions. Meanwhile, untreated plants or treated with high level of micronutrients under well watered plants gave (19.59 and $19.87 \mathrm{~g}$ ). 


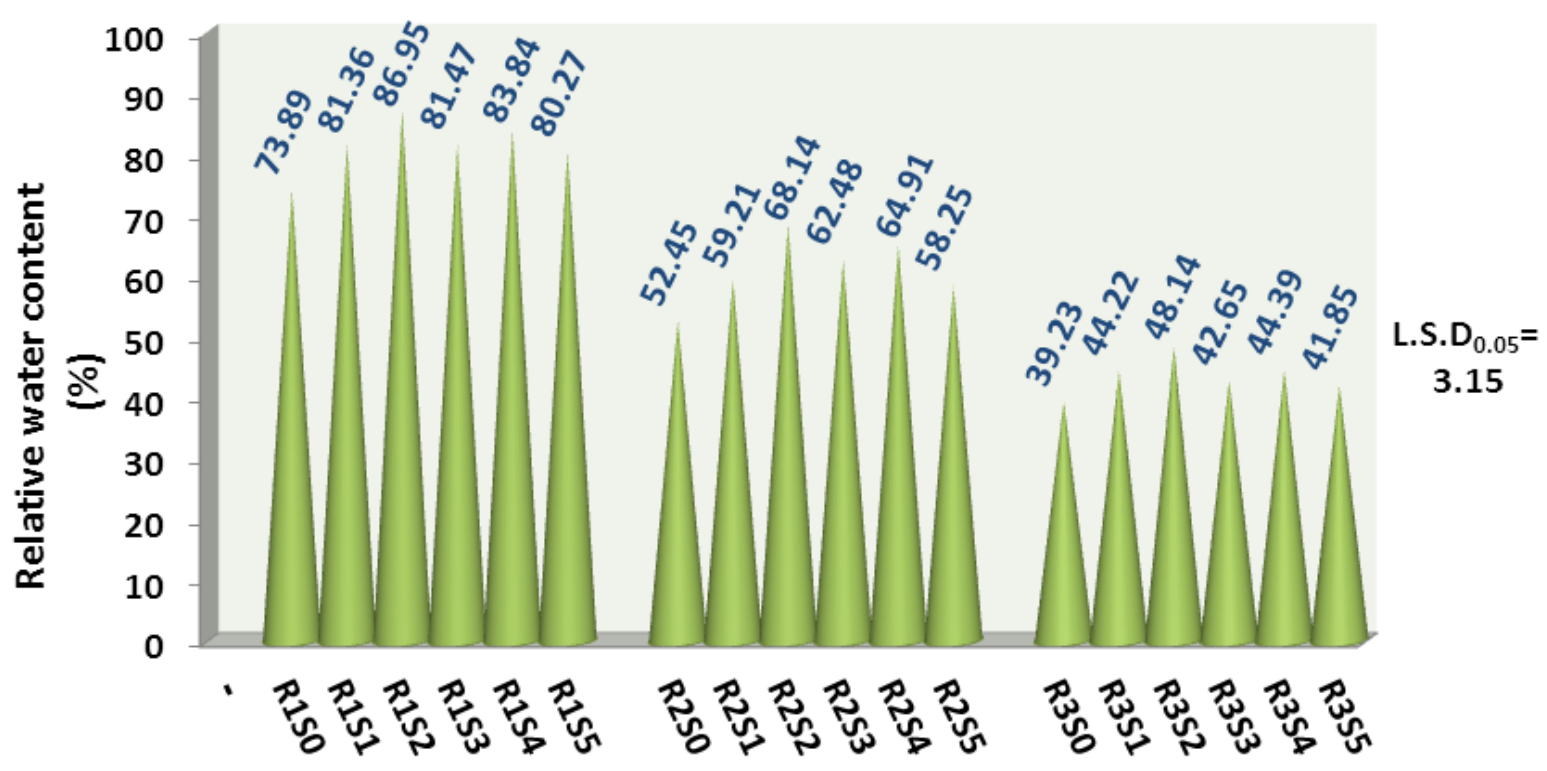

Figure 3. Effect of the interaction between water stress (R) and foliar spray (S) by AsA and micronutrients on Relative water content (\%) of maize at 85 days from planting in 2017 season.

S0: untreated plants, S1: spray with $250 \mathrm{ppm}$ AsA, S2: $350 \mathrm{ppm}$ AsA, S3: 450 ppm ASA,

S4: spray with $100 \%$ micronutrient recommended dose and S5: $150 \%$ micronutrient.

R1: well-watered ( $\left.3750 \mathrm{~m}^{3} / \mathrm{fad}\right)$; R2: 0.8 R1, R3: 0.6 of R1.

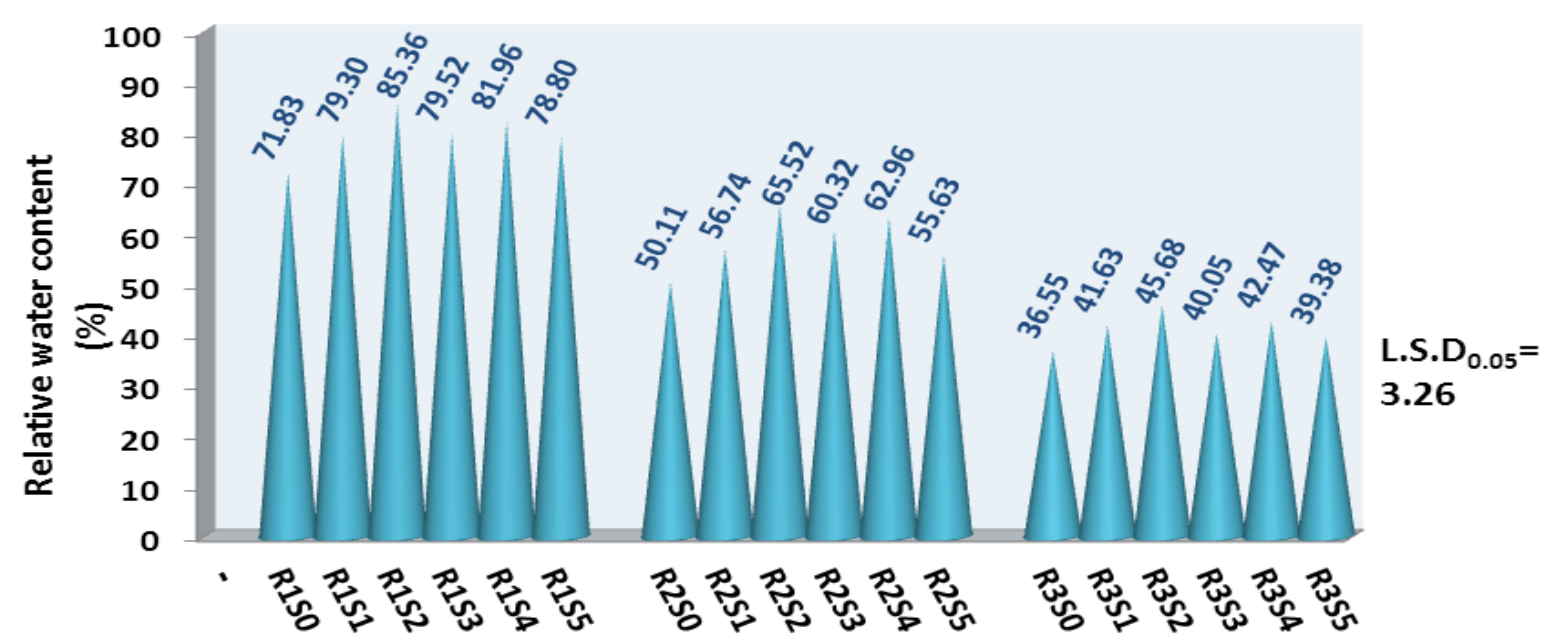

Figure 4. Effect of the interaction between water stress (R) and foliar spray (S) by AsA and micronutrients on Relative water content (\%) of maize at 85 days from planting in 2018 season.

S0: untreated plants, S1: spray with $250 \mathrm{ppm}$ AsA, S2: $350 \mathrm{ppm}$ AsA, S3: 450 ppm ASA,

S4: spray with $100 \%$ micronutrient recommended dose and S5: $150 \%$ micronutrient. R1: well-watered ( $3750 \mathrm{~m}^{3}$ /fad); R2: 0.8 R1, R3: 0.6 of R1. 


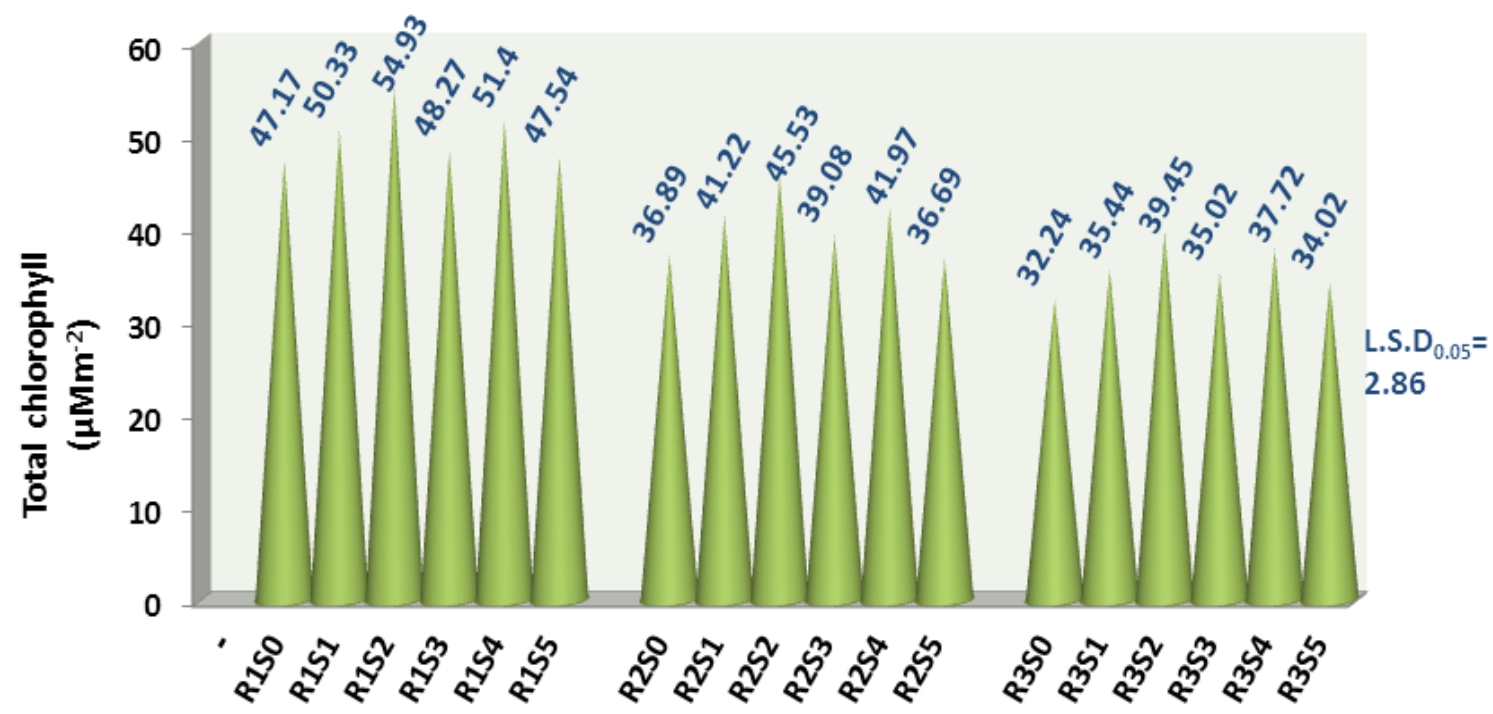

Figure 5. Effect of the interaction between water stress (R) and foliar spray (S) by AsA and micronutrients on Total chlorophyll $\left(\mu \mathrm{Mm}^{-2}\right)$ of maize at 85 days from planting in 2017 season. S0: untreated plants, S1: spray with $250 \mathrm{ppm}$ AsA, S2: 350 ppm AsA, S3: 450 ppm ASA, S4: spray with 100\% micronutrient recommended dose and S5: $150 \%$ micronutrient. R1: well-watered ( $\left.3750 \mathrm{~m}^{3} / \mathrm{fad}\right)$; R2: $0.8 \mathrm{R} 1, \mathrm{R} 3: \mathbf{0 . 6}$ of R1.

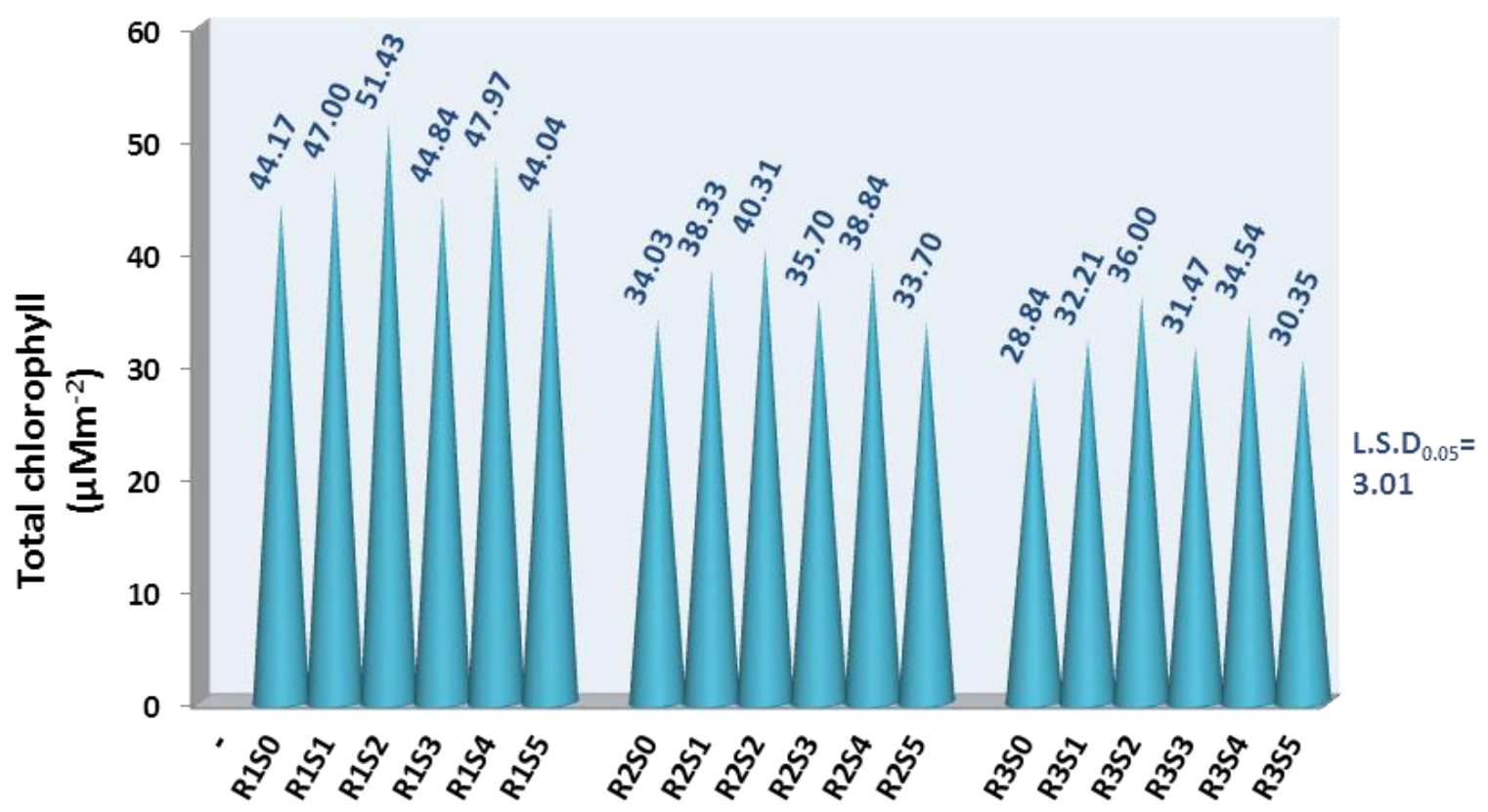

Figure 6. Effect of the interaction between water stress (R) and foliar spray (S) by AsA and micronutrients on Total chlorophyll $\left(\mu \mathrm{Mm}^{-2}\right)$ of maize at 85 days from planting in 2018 season. S0: untreated plants, S1: spray with 250 ppm AsA, S2: 350 ppm AsA, S3: 450 ppm ASA, S4: spray with $100 \%$ micronutrient recommended dose and S5: $150 \%$ micronutrient. R1: well-watered ( $3750 \mathrm{~m}^{3} / \mathrm{fad}$ ); R2: 0.8 R1, R3: 0.6 of R1. 


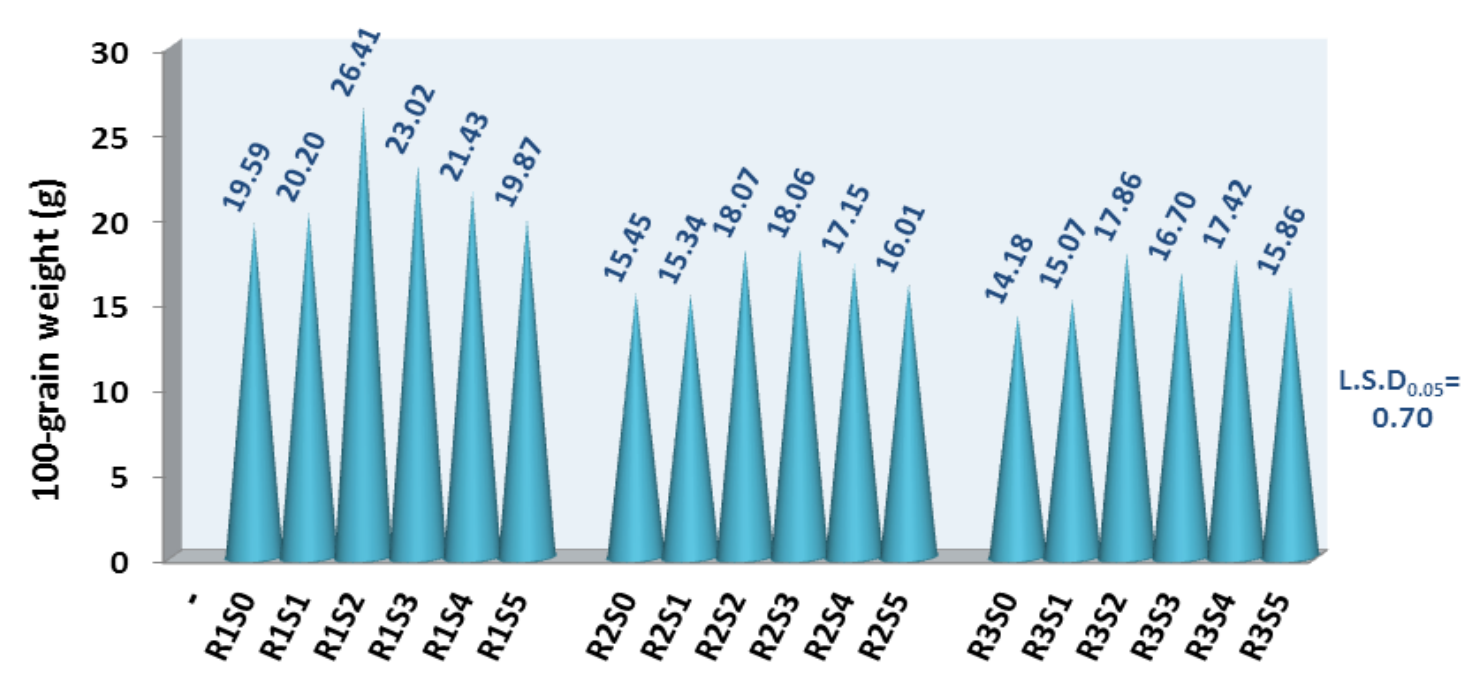

Figure 7. Effect of the interaction between water stress (R) and foliar spray (S) by AsA and micronutrients on 100-grain weight $(\mathrm{g})$ of maize at harvest in 2018 season.

S0: untreated plants, S1: spray with 250 ppm AsA, S2: 350 ppm AsA, S3: 450 ppm ASA, S4: spray with $100 \%$ micronutrient recommended dose and S5: $150 \%$ micronutrient. R1: well-watered ( $\left.3750 \mathrm{~m}^{3} / \mathrm{fad}\right)$; R2: 0.8 R1, R3: 0.6 of R1

In addition, the lowest 100-grain weight (14.18 g) was significantly obtained from the interaction between untreated plants and severe water stress in comparison with 17.86 and $17.42 \mathrm{~g}$ which obtained from the intermediate level of ascorbic acid $(350 \mathrm{ppm})$ and recommended dose of micronutrients mixture, respectively (Fig. 7). It has been reported that maize is relatively tolerant to water stress in the vegetative stage, very sensitive during the period of tasseling, silking, and pollination, and moderately sensitive during the grain-filling stage as reported by several searchers such as Shanahan and Nielsen (1987). Also, Muhammad et al. (2001) observed that increasing water stress significantly decreased 100- grain weight of maize. Under severe water stress conditions, it could be concluded that both of foliar spray by AsA and micronutrients mixture had the same effects on 100-grain weight and significantly ameliorated 100-grain weight by about 26 and 23\% compared to untreated plants (spray with water), respectively. Meanwhile, under moderate water stress conditions (Irrigation by $0.8 \mathrm{ETc}$ ), using $350 \mathrm{ppm} \mathrm{AsA}$ significantly ameliorated 100 -grain weight by about $17 \%$ compared to untreated plants in the second season (Fig. 7). It could be concluded that under stressed and unstressed plants both of foliar spray of AsA and micronutrients mixture significantly ameliorated 100- grain weight compared to untreated plants. These results are in a good relation with those obtained by Kotb and Elhamahmy, (2013) Abo-Marzoka et al., (2016), Ramanjineyulu et al., (2018), Qasim et al., (2019) and El-Yazal (2019).

\section{Grain yield (kg/fad.)}

Relative to the interaction between irrigation treatments and foliar spray treatments, results of both seasons showed that both of them interacted with each other significantly for grain yield/fad., (Figs. 8 and 9). Under full irrigation, the intermediate concentration of AsA and recommended dose of micronutrients significantly gave higher grain yields (4839.95 and 4687.45 $\mathrm{Kg} / \mathrm{fad}$.) compared to $(4022.18 \mathrm{Kg} / \mathrm{fad})$ which were obtained from untreated plants in 2017 season. The relative increase percentages in grain yield due to using $350 \mathrm{ppm}$ AsA and recommended dose of micronutrients were about $20 \%$ and $17 \%$ compared with untreated plants, respectively.

Also, under severe water stress (irrigation by $60 \% \mathrm{Etc})$; the intermediate concentration of AsA significantly produced $3766.63 \mathrm{Kg}$ grain/ fad., compared to $3220.81 \mathrm{Kg} / \mathrm{fad}$., which was obtained from untreated plants in 2017 season. The relative increase percentages in grain yield due to using this level of AsA was about $17 \%$ compared with untreated plants. Meanwhile, under 


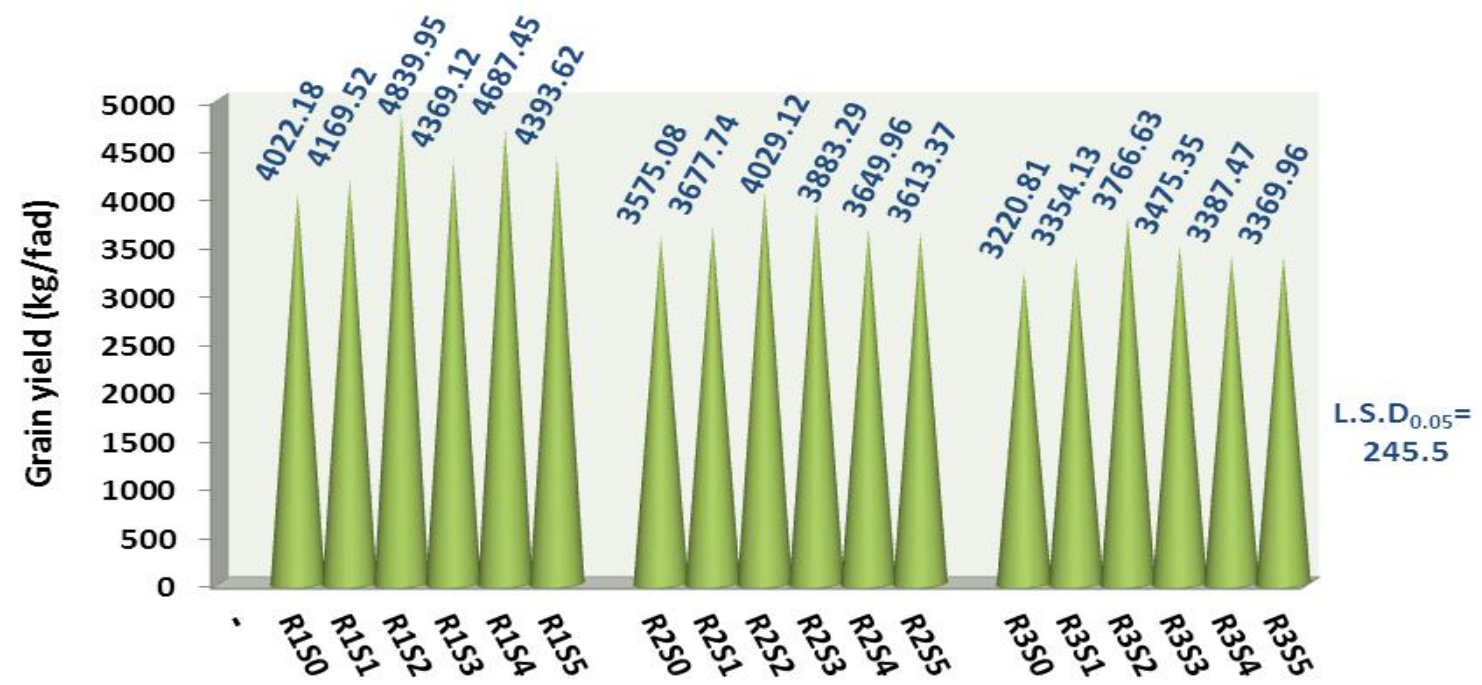

Figure 8. Effect of the interaction between water stress (R) and foliar spray (S) by AsA and micronutrients on Grain yield $(\mathrm{kg} / \mathrm{fad})$ of maize at harvest in 2017 season.

S0: untreated plants, S1: spray with $250 \mathrm{ppm}$ AsA, S2: $350 \mathrm{ppm}$ AsA, S3: $450 \mathrm{ppm}$ ASA, S4: spray with $100 \%$ micronutrient recommended dose and S5: 150\% micronutrient.

R1: well-watered ( $3750 \mathrm{~m}^{3}$ /fad); R2: 0.8 R1, R3: 0.6 of R1

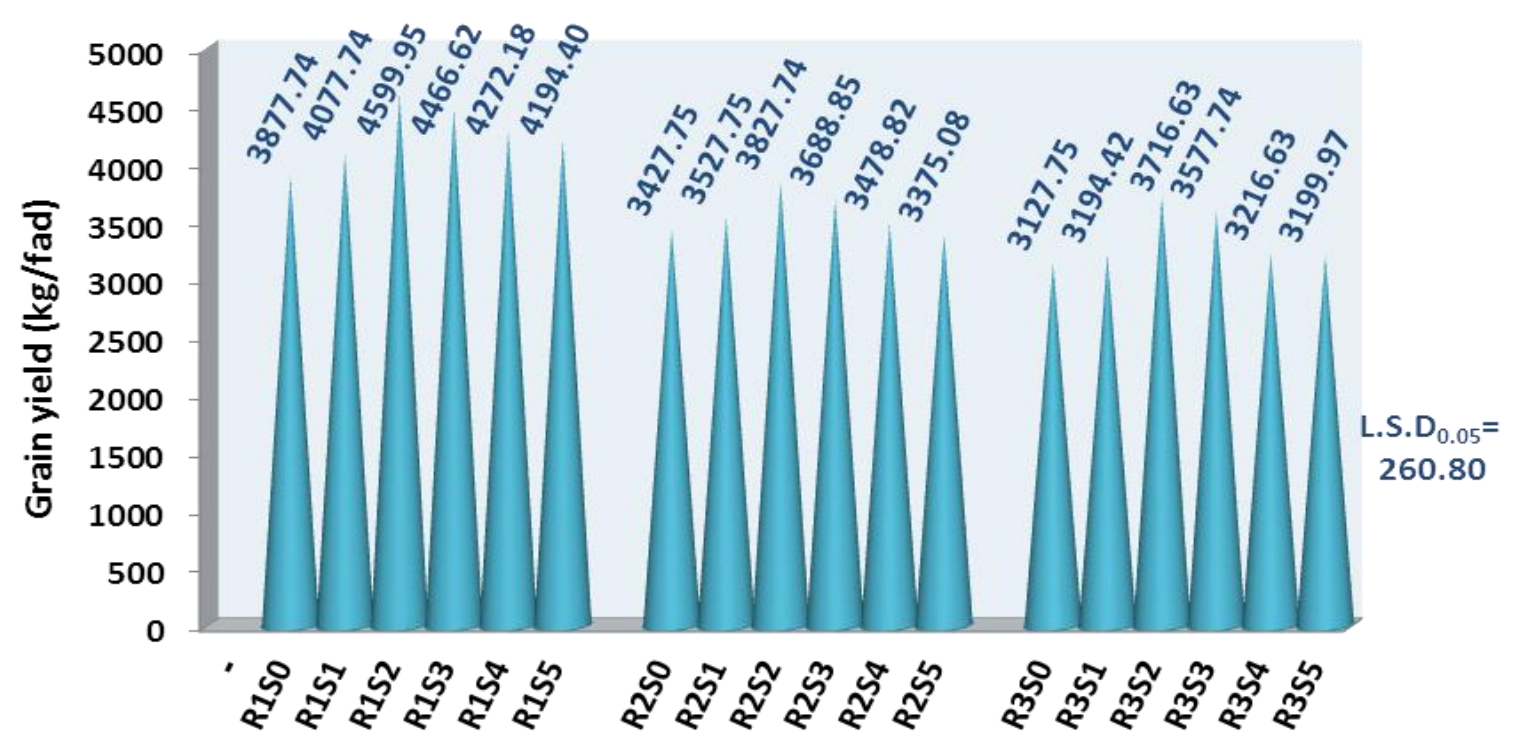

Figure 9. Effect of the interaction between water stress (R) and foliar spray (S) by AsA and micronutrients on Grain yield $(\mathrm{kg} / \mathrm{fad})$ of maize at harvest in 2018 season.

S0: untreated plants, S1: spray with 250 ppm AsA, S2: 350 ppm AsA, S3: 450 ppm ASA,

S4: spray with 100\% micronutrient recommended dose and S5: 150\% micronutrient. R1: well-watered ( $3750 \mathrm{~m}^{3} / \mathrm{fad}$ ); R2: 0.8 R1, R3: 0.6 of R1 
moderate water stress, the intermediate and high concentrations of AsA significantly recorded 4029.12 and $3883.29 \mathrm{Kg}$ grain/fad., in comparison with $3575.08 \mathrm{Kg}$ grain/fad., which was obtained from untreated plants in 2017 season (Fig. 8). The relative increase percentages in grain yields due to using these levels of AsA and micronutrients were about $13 \%$ and $9 \%$ compared with untreated plants, respectively.

On the other hand, the results of the Fig. 9 explained that, under well-watered plants (3750 $\mathrm{m}^{3} / \mathrm{fad}$.), the intermediate and high levels of AsA significantly gave the highest grain yields (4599.95 and $4466.62 \mathrm{Kg} / \mathrm{fad}$.) compared to ( $3877.74 \mathrm{Kg} / \mathrm{fad}$.) which was obtained from untreated plants in the second year. The relative increase percentages in grain yields due to using these levels of AsA were about 19\% and 15\% compared with untreated plants, respectively, (Fig. 9). Also, under moderate and severe water stress (irrigation by $80 \%$ and $60 \%$ Etc., respectively); the two same levels of AsA significantly produced $(3827.74$ and $3688.85 \mathrm{Kg}$ grain/fad.) and (3716.63 and $3577.74 \mathrm{Kg}$ grain/ fad.) compared to 3427.75 and $3127.75 \mathrm{Kg} / \mathrm{fad}$. which was obtained from untreated plants, respectively, in 2018 season. Under moderate and severe water stress conditions, the relative increase percentages in grain yields due to using the levels of 350ppm AsA were about $12 \%$ and $19 \%$ compared with untreated plants, respectively, (Fig. 9).

It could be concluded that under stressed and unstressed plants both of foliar spray of AsA and micronutrients mixture significantly ameliorated grain yields, however, the effect of foliar spraying with ascorbic acid on corn production was greater than micronutrients mixture. In the same direction, under water deficit conditions, growth, relative water content (RWC) and total chlorophyll as well as grain yield significantly decreased in maize plants compared to those traits under control conditions (Kotb et al., (2009; Qasim et al., 2019; Moharramnejad et al., 2019). The positive effect of AsA and micronutrients on increasing grain yield might be due to their important roles in enhancing enzymes activity and photosynthetic pigment content in turn of enhancing plant metabolism which reflect favorably on yield attributes such as length, diameter and weight of ears as well as 100 grain weight and finally increased grain yield/fad of corn plants. These results are in a good connection with those obtained by (Abd El-Aziz et al., (2007) and Zhang et al., 2019), they noticed that, foliar application of vitamin $\mathrm{C}$ significantly ameliorated the growth and productivity in many plants under normal conditions. In general, the results of Dolatabadian et al. (2010) reported that ascorbic acid improved the negative effects of water stress and increased growth and productivity at normal and stressed conditions. Also, under water deficit, foliar application of several concentrations of ascorbic acid on corn plants alleviated the adverse effect of water stress and significantly improved the growth, yield and yield attributes of maize plants (Abo-Marzoka et al., (2016) and (Qasim et al., 2019). It has been reported that foliar application of micronutrients is an easy and simple method for improvement of plant nutritional condition for maize Grzebisz et al. (2008). Hussain et al. (2011) found that $\mathrm{Zn}, \mathrm{Fe}$ and $\mathrm{Mn}$ significantly enhanced grains/ear and grain weight of corn. In the same direction, Yarnia et al (2013) noticed that a mixture of all combinations of $\mathrm{N}$, $\mathrm{Mg}, \mathrm{Zn}, \mathrm{Mn}, \mathrm{B}$, at all stages had the highest grain yield of corn compared to untreated plants. Also, weight of 100 grain as well as grains (ardab/fad) were positively affected by foliar spraying with the mixture of triple micronutrients of $\mathrm{Fe}, \mathrm{Mn}$ and $\mathrm{Zn}$ compared to untreated plants of maize plant (Zea mays L. cv single hybrid 10) (Siam et al 2013).

\section{Irrigation water use efficiency $\left(\mathrm{kg} \mathrm{m}^{-3}\right)$}

Concerning to the interaction between irrigation treatments and foliar spray treatments, results of both seasons showed that both of them interacted with each other significantly with irrigation water use efficiency (Figs. 10 and 11). Without a doubt, under moderate and severe water stress conditions, exogenous application of $350 \mathrm{ppm}$ AsA gave significant values from IWUE in both seasons followed by micronutrients mixture with significant differences among them in comparison with untreated plants under the same conditions. Also, the highest significant values from IWUE in both years were obtained from $350 \mathrm{ppm}$ AsA under severe water stress conditions and the opposite; the lowest significant values from IWUE in both years were obtained from untreated plants under well watered (Figs. 10 and 11). On the other hand, under well watered plants, the data recorded in Fig. 10 reveled that 


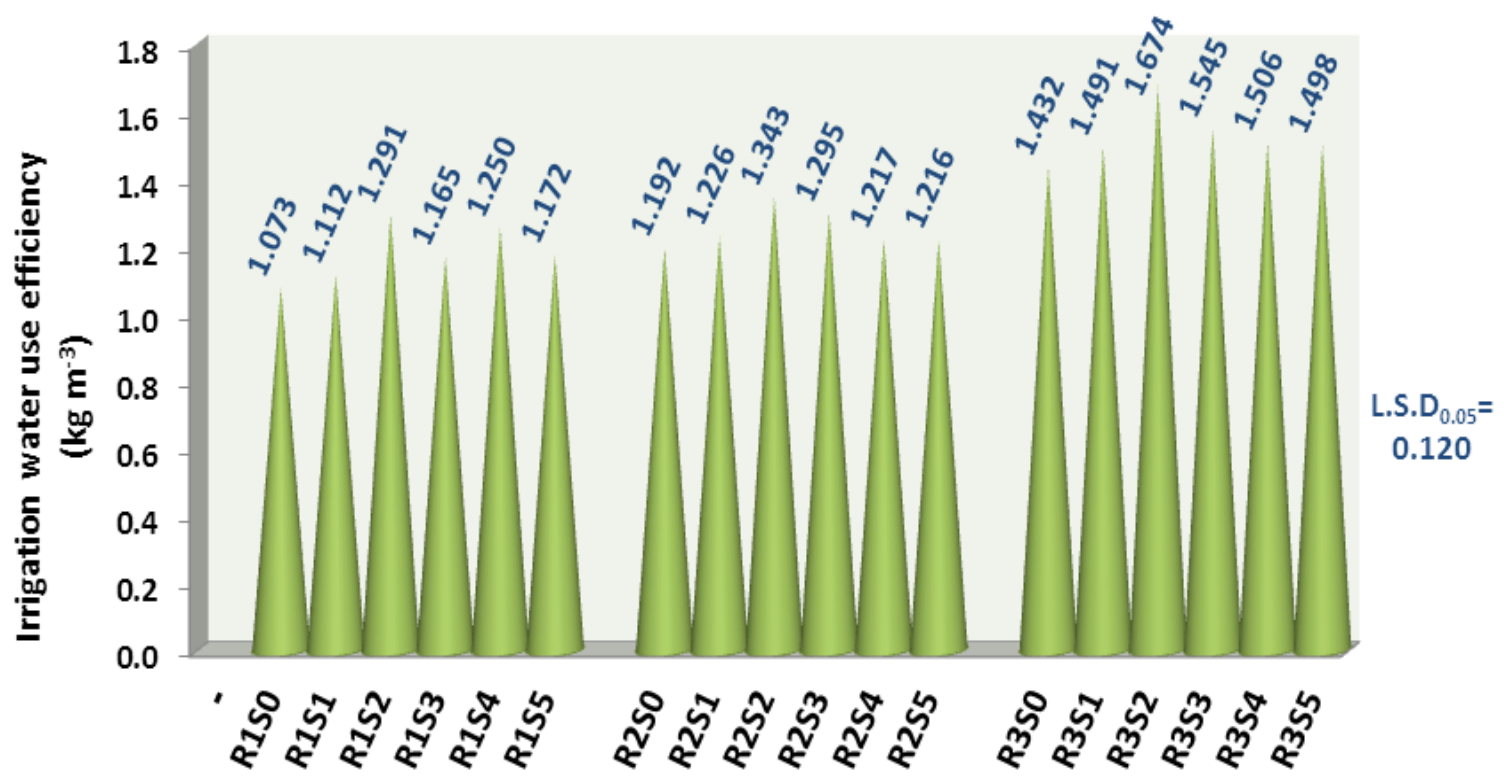

Figure 10. Effect of the interaction between water stress (R) and foliar spray (S) by AsA and micronutrients on Irrigation water use efficiency $\left(\mathrm{kg} \mathrm{m}^{-3}\right)$ of maize at harvest in 2017 season. so: untreated plants, S1: spray with 250 ppm AsA, S2: 350 ppm AsA, S3: 450 ppm ASA, S4: spray with $100 \%$ micronutrient recommended dose and S5: $150 \%$ micronutrient. R1: well-watered ( $\left.3750 \mathrm{~m}^{3} / \mathrm{fad}\right)$; R2: $0.8 \mathrm{R} 1$, R3: 0.6 of R1

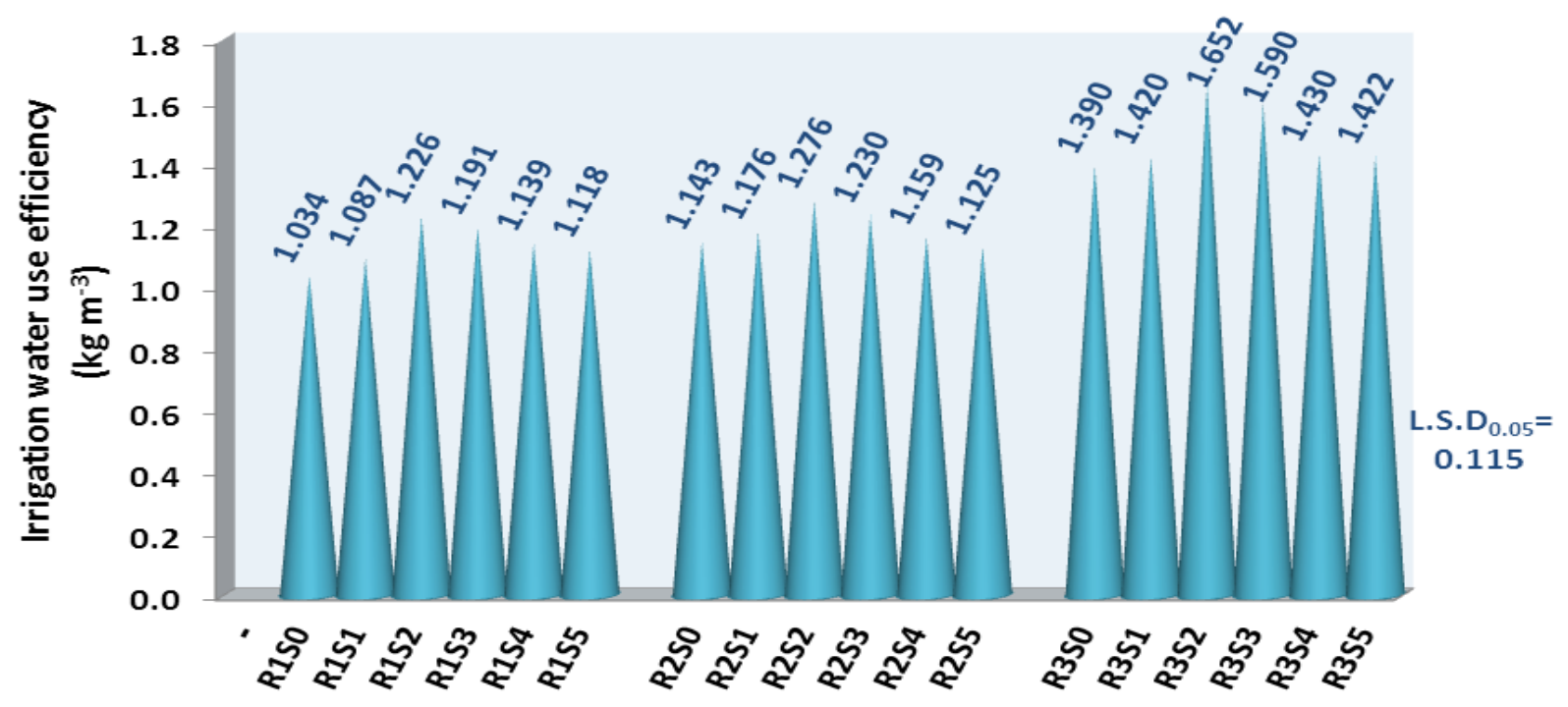

Figure 11. Effect of the interaction between water stress (R) and foliar spray (S) by AsA and micronutrients on Irrigation water use efficiency $\left(\mathrm{kg} \mathrm{m}^{-3}\right)$ of maize at harvest in 2018 season. S0: untreated plants, S1: spray with 250 ppm AsA, S2: 350 ppm AsA, S3: 450 ppm ASA, S4: spray with 100\% micronutrient recommended dose and S5: 150\% micronutrient. R1: well-watered ( $3750 \mathrm{~m}^{3} / \mathrm{fad}$ ); R2: $0.8 \mathrm{R1}, \mathrm{R3}: 0.6$ of R1 
using $350 \mathrm{ppm}$ AsA or recommended dose of micronutrients mixture gave the highest significant values from IWUE without significant differences between them relative to untreated plants. It could be concluded that IWUE responded to AsA and micronutrients under stress condition as well as full irrigation. These results are a good connection with those obtained by Bakry et al. (2013). They reported that under water stress conditions (80\% Etc), increasing exogenous application of ascorbic acid up to $(300 \mathrm{mg} / \mathrm{L})$ significantly increased grain yield and irrigation water use efficiency. Their results indicated also that the interaction between the water stress of $(80 \%$ Etc) and (300 $\mathrm{mg} / \mathrm{L}$ ) ascorbic acid significantly produced the maximum values of grain yield and water use efficiency and outyielded the other all interactions. Under newly reclaimed sandy soil, they can save about $20 \%$ of irrigation water by foliar application of ascorbic acid up to (300 $\mathrm{mg} / \mathrm{L}$ ). The positive effects of AsA on plants were in conformity with those recorded by Kotb and Elhamahmy (2013) and Kotb (2014). Waraich et al. (2011) found that the micronutrients like $\mathrm{Fe}, \mathrm{B}, \mathrm{Mn}$ and $\mathrm{Mo}$ can enhance and improve the IWUE by alleviating the adverse effects of water stress indirectly by activating several metabolisms in crop plants like physiological, biochemical and metabolic processes. Also, they concluded that using some nutrients such as $\mathrm{N}, \mathrm{K}, \mathrm{Mg}, \mathrm{B}, \mathrm{Zn}$ and $\mathrm{Si}$ decrease the toxicity of reactive oxygen species produced under water-stress conditions by enhancing the activities of several antioxidants like superoxide dismutase, peroxidase and catalase in the cells of plant. These antioxidant enzymes have the ability to reduce photooxidative stress, scavenge ROS, maintain the integrity of chloroplast membrane and finally, increase the photosynthetic rate in the crop plants which in turn enhances the IWUE and plant production (Waraich et al., 2011).

Conclusively, from these results, it could be concluded that the interactions between drought stress and AsA or micronutrients were significant, indicating that these non-enzymatic antioxidants and micronutrients by a proper level have the ability to play important roles for minimizing the adverse effect of water stress and hence improved growth, water use efficiency and grain yield under new soil conditions.

\section{REFERENCES}

Abd El-Aziz, N.G., F.E.M. El-Quesni and M.M Farahat (2007). Response of vegetative growth and some chemicals constituents of syngonium podophyllum $\mathrm{L}$. to foliar application of Thiamine, Ascorbic Acid and Kinetin at Nubaria. World J. Agric. Sci., 3: 301-305.

Abo-Marzoka, E.A., R.F.Y. El-Mantawy and I.M. Soltan (2016). Effect of irrigation intervals and foliar spray with salicylic acid and ascorbic acid on maize. J. Agric. Res. Kafr El-Sheikh Univ., 42 (4): 506-518.

Allen, R.G., L.S. Pereira, D. Raes and M. Smith (1998). Crop Evapotranspiration Guidelines for Computing Crop Water Requirements (Irrigation and drainage paper 56). FAO of the United Nations, Rome, Italy.

Allen, R.G., M. Smith, O. Willian, W.O. Pruitt and L.S. Pereira (1996). Modifications to the FAO crop coefficient approach. In: Proceedings of the International Conference on Evapotranspiration and Irrigation Scheduling, Ame. Soc. Agric. Eng., San Antonio, TX, USA, Nov., 3(6):132-142.

Anjum, F., M. Yaseen, E. Rasul, A. Wahid and S. Anjum (2003). Water stress in barley (Hordeum vulgare L.). I. Effect on morphological characters. Pak. J. Agric. Sci., 40: 43-44.

Apel, K. and H. Hirt (2004). Reactive oxygen species: metabolism, oxidative stress, and signal transduction. Ann. Rev. Plant Biol., 55: 373-399.

Bakry, A.B., R.E. Abdelraouf and M. Ahmed (2013). Effect of drought stress and ascorbic acid foliar application on productivity and irrigation water use efficiency of wheat under newly reclaimed sandy soil. Elixir Agric., 57A: 14398-14403.

Cassel, D.K. and D.R. Nielsen (1986). Field capacity and available water capacity. Methods of Soil Analysis. Part I. Physical and Mineralogical Methods. Agronomy Monograph No. 9, In: Klute, A. (Ed.) Soil Sci. Soc. Am., Madison, Wisconsin, 901-926. 
Dolatabadian, A., S.A.M. Modarressanavy and K.S. Asilan (2010). Effect of ascorbic acid foliar application on yield, yield component and several morphological traits of grain corn under water deficit stress conditions. Notulae Scientia Biologicae., 2(3): 45-50.

El-Yazal, M.A.S (2019). The Application of Citric Acid in Combination with Some Micronutrients Increases the Growth, Productivity and a Few Chemical Constituents of Maize (Zea Mays L.) Plants. Int. Letters of Nat. Sci., 76: 86-97.

Farahat, M.M., M.M.I. Soad, S.T. Lobna and F.E.M El-Quesni (2007). Response of vegetative growth and some chemical constituents of Cupressus sempervirens L. to foliar application of ascorbic acid and zinc at Nubaria. World. J. Agric. Sci., 3: (4) 694502.

Farooq, M., A. Wahid, N. Kobayashi, D. Fujita and S.M.A. Basra (2009). Plant drought stress: effects, mechanisms and management. Agron. Sustain. Dev., 29: 185- 212.

FAO STAT, F. (2020). Available online, Food and Agriculture, Organization of the United Nations Resources, Rome, Italy: http:// www. Fao. org/faostat/en/data.

Foyer, C. (1993). Ascorbic acid. In: Antioxidants in Higher Plants. R.G. Alscher and J.L. Hess (eds) CRC Press, Boca Raton, 31-58.

Grossmann, R.B. and T.G. Reinsch (2002). Bulk density and linear extensibility, in: Methods of Soil Analysis. Part 4. Physical Methods. SSSA Book Series, No. 5, Soil Sci., Soci., Am., Madison, Wisconsin, 201-228.

Grzebisz, W., M. Wrońska, J.B. Diatta and P. Dullin (2008). Effect of zinc foliar application at early stages of maize growth on patterns of nutrients and dry matter accumulation by the canopy. Part I. Zinc uptake patterns and its redistribution among maize organs. J. Elementol., 13:17-28.

Hussain, M., A.M. Jahiruddin and F. Khatun (2011). Response of maize varieties to zinc fertilization. Bangladesh J. Agric. Res., 36 (3): 437-447.
Jaleel, C.A., R. Gopi and R. Panneerselvam (2008). Growth and photosynthetic pigments responses of two varieties of Catharanthus roseus to triadimefon treatment. Comp. Rend. Biol., 331: 272-277.

Kotb, M.A. and M.A.M. Elhamahmy (2013). Foliar application of ascorbic acid improved drought tolerance and productivity of wheat (Triticum aestivum L.). J. Plant Prod. Sci., Suez Canal Univ., 1: 1-16.

Kotb, M.A. (2014). Effect of foliar application of non-enzymatic antioxidants on peanut yield and its quality under induced water stress conditions. Zagazig J. Agric. Res., 41 (5): 931-947.

Kotb, M.A., A.A. Mansour and A.B. Gaballah (2009). Improving water use efficiency and yield of maize (Zea mays, L.) by foliar application of glycinbetaine under induced water stress conditions. J. Prod. and Dev., 14 (2): $411-433$.

Lawlor, D.W. and G. Cornic (2002). Photosynthetic carbon assimilation and associated metabolism in relation to water deficits in higher plants. Plant Cell Environ., 25: 275-294.

MarkweL, J., J.C. Osterman and J.L. Mitchell (1995). Calibration of Minotta SPAD-502 leaf chlorophyllmeter. Photosynthetic Res., 46: 467-472.

Massacci, A., S.M. Nabiev, L. Pietrosanti, S.K. Nematov, T.N. Chernikova, K. Thor and J. Leipner (2008). Response of the photosynthetic apparatus of cotton (Gossypium hirsutum) to the onset of drought stress under field conditions studied by gas exchange analysis and chlorophyll fluorescence imaging. Plant Physiol. and Biochem., 46: 189-195.

Moharramnejad, S., O. Sofalian, M. Valizadeh, A. Asghari, M.R. Shiri and M. Ashraf (2019). Response of maize to field drought stress: Oxidative defense system, osmolytes accumulation and photosynthetic pigments. Pak. J. Bot., 51 (3): 799-807.

Muhammad, B.K., N. Hussain and M. Iqbal (2001). Effect of water stress on growth and yield components of maize variety YHS202. J. Res. Sci., 12 (1): $15-18$. 
Neale, C.M.U., R.H. Ahmed, M.S. Moran, J.P. Pinter, J. QI and T.R. Clarke (1996). Estimating cotton seasonal evapotranspiration using canopy reflectance. Proc. Int. Conf. Evapotranspiration and Irrigation Scheduling, Ame. Soc. Agric. Eng., San Antonio, Texas, USA, Nov., 3(6):173-181.

Premachandra, G.S., H. Saneoka, K. Fujita and S. Ogata (2008). Water stress and potassium fertilization in field grown maize (Zea mays L.): Effects on leaf water relations and leaf rolling. J. Agron. and Crop Scie., 170 (3): 195-201.

Qasim, M., M. Aziz, F. Nawaz and M. Arif (2019). Role of salicylic acid and ascorbic acid in alleviating the harmful effects of water stress in Maize (Zea mays L.). Asian J. Agric. Biol., 7 (3):442-449.

Rahman, M.T., M.R. Islam, M.M. Hasani, M.F. Ikpali, A.N.A. Haquai, S.M. Shamsuzzaman and M.Y. Rafit (2017). Effects of micronutrient on growth and micronutrient content of hybrid maize (Zea mays L.). Bangladesh J. Bot., 46 (1): 527-532.

Ramanjineyulu, M., M. Srinivasa Reddy, P.V. Ramesh Babu and P. Kavitha (2018). Effect of secondary and micronutrients on yield forming traits of maize (Zea mays L.). Int. J. Curr. Microbiol. App. Sci., 7 (7): 1125-1131.

Reddy, A.J. and Rao, I.M. (1968). Influence of induced water stress on chlorophyll components of proximal and distal leaflets of groundnut plants. Curr. Sci., 5 (3): 118-121.

Sajedi, N.A., M.R. Ardakani, H. Madani, A. Naderi and M. Miransari (2011). The effects of selenium and other micronutrients on the antioxidant activities and yield of corn ( $\mathrm{Zea}$ mays L.) under drought stress. Physiol. Mol. Biol. Plants, 17(3):215-222.

Schonfeld, M.A., R.C. Johnson, B.F. Carver and D.W. Mornhinweg (1988). Water relations in winter wheat as drought resistance indicators. Crop Sci., 28: 536-541.

Shanahan, J.F. and D.C. Nielsen (1987). Influence of growth retardants (Anti-Gibberellins) on corn vegetative growth, water use, and grain yield under different levels of water stress. Agron. J., 79: 103-109.

Shlemmer, M.R., D.D. Francis, J.F. Shanahan and J.S. Schepers (2005). Remotely measuring chlorophyll content in corn leaves with differing nitrogen levels and relative water content. Agron. J., 97: 106-112.

Siam, H.S., M.G. Abd-El-Kader and M.S. Abd El-Fattah (2013). Effect of ammonia gas and some micronutrients by different methods on maize plants (Zea mays L.). II- Yield, yield attributes micronutrients contents. J. Appl. Sci. Res., 9 (3): 1815-1830.

Smirnoff, N. (1993). The role of active oxygen in the response of plants to water deficit and desiccation. New Phytol., 125: 27-58.

Steel, G.D., J.H. Torrie and D.A. Diskey (1997). Principles and Procedures of Statistics: A Biometrical Approach. $3^{\text {rd }}$ Ed. Mc. GrawHill, New York.

Tohidi Moghadam, H.R., H. Zahedi and A. Ashkiani1 (2013). Effect of zinc foliar application on auxin and gibberellin hormones and catalase and superoxide dismutase enzyme activity of corn (Zea mays L.) under water stress. Maydica Electronic Publication, 58: 218-223.

Waraich, E.A., R. Ahmed, M. Ashraf, Y. Saifullah and A. Mahmood (2011). Improving agricultural water use efficiency by nutrient management in crop plants. Acta Agriculturae Scandinavica Section. Soil and Plant Sci., 61: 291-304.

Wasaya, A., M.S. Shabir, M. Hussain, M. Ansar, A. Aziz, W. Hassan and I. Ahmad (2017). Foliar application of zinc and boron improved the productivity and net returns of maize grown under rainfed conditions of pothwar plateau. J. Soil Sci. and Plant Nutr., 17 (1): 33-45.

Xiong, L. and J.K. Zhu (2002). Molecular and genetic aspects of plant responses to osmotic stress. Plant, Cell and Environ., 25:131-139.

Yarnia, M., Khalilvand E. Behrouzyar, F.R. Khoii, M. Mogaddam and M.N. Safarzadeh Vishkaii (2013). Effects of methanol and some micro-macronutrients foliar applications on maize (Zea mays L.) maternal plants on subsequent generation yield and reserved mineral nutrients of the seed. Afr. J. Agric. Res., 8 (7): 619-628.

Zhang, K., G. Wang, M. Bao, L. Wang and X. Xie (2019). Exogenous application of ascorbic acid mitigates cadmium toxicity and uptake in Maize (Zea mays L.). Environ. Sci. and Pollution Res., 26 (19): 19261-19271. 


\title{
تاثير تداخل الفعل بين الإجهاد المائي والرش الورقي بحمض الأسكوربيك اوالعناصر الصغرى على التى
} إنتاجية الذرة الثامية وكفاءة استخدام مياه الرئي الرئي

\author{
مـاهر عبد الله قطب ـ احمد عوض محمد ـ محمد محمد محمد السيد ـ منال شكرى عبد الحليم

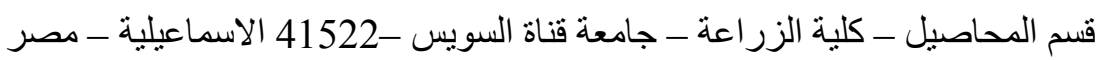

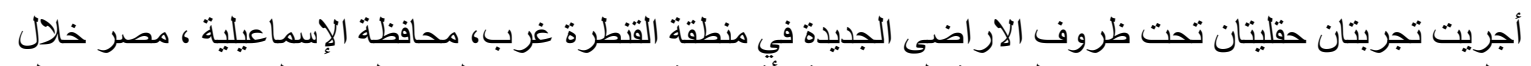

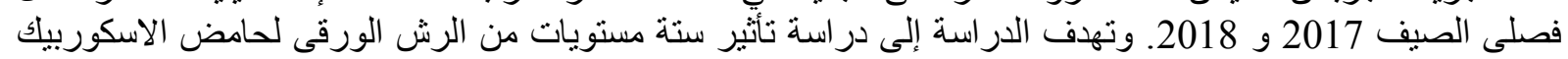

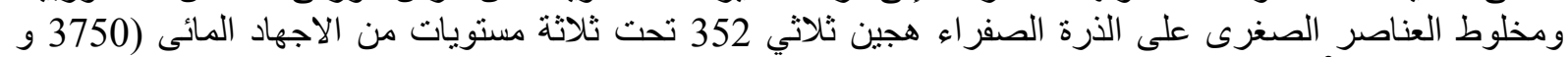

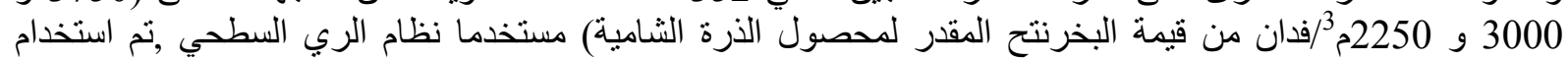

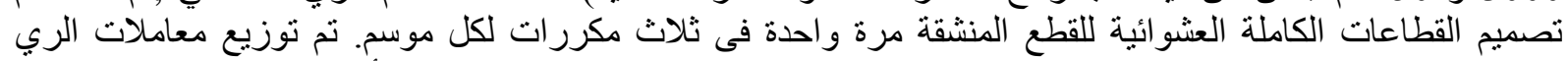

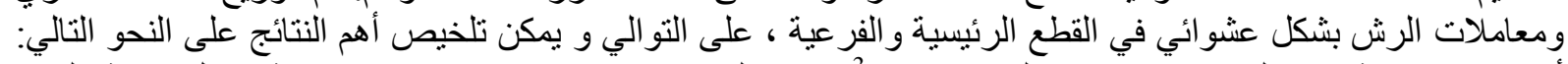

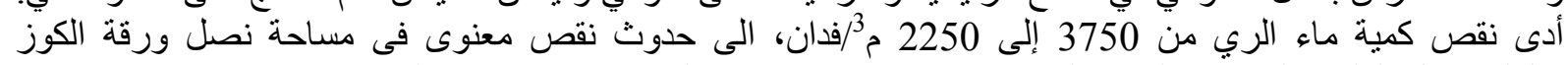

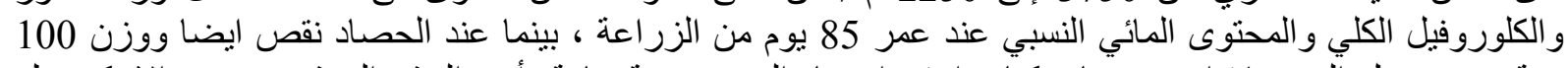

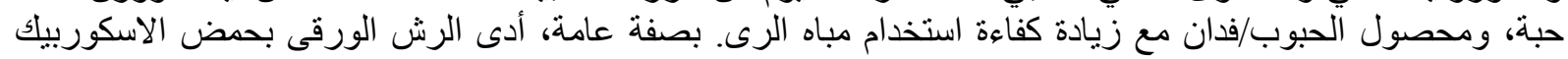

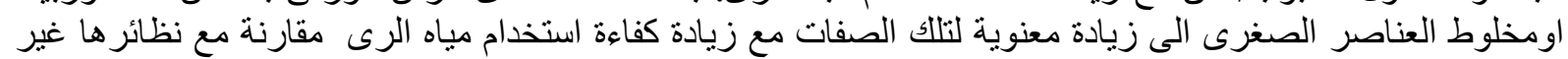

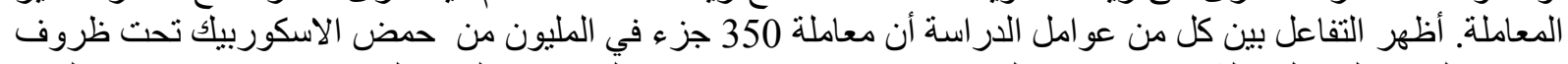

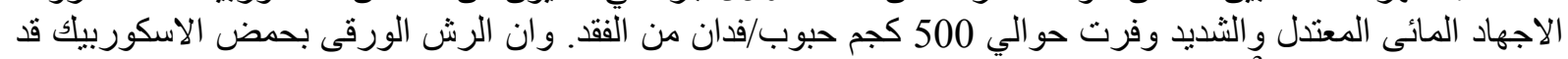

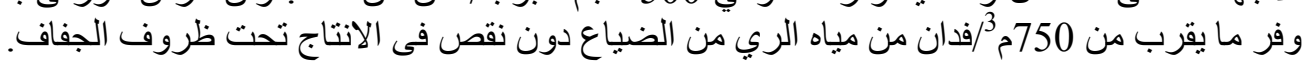

أستاذ المحاصيل المتفرغـ كلية التكنولوجيا والتنمية- جامعة الزقازيق.

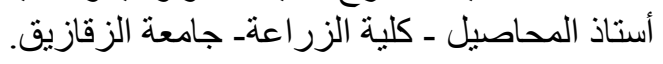

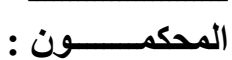

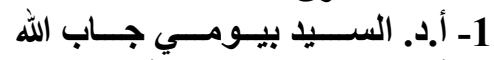
2- أ.د. عبدالرحمن السيد أحمد عمر جاب الر 